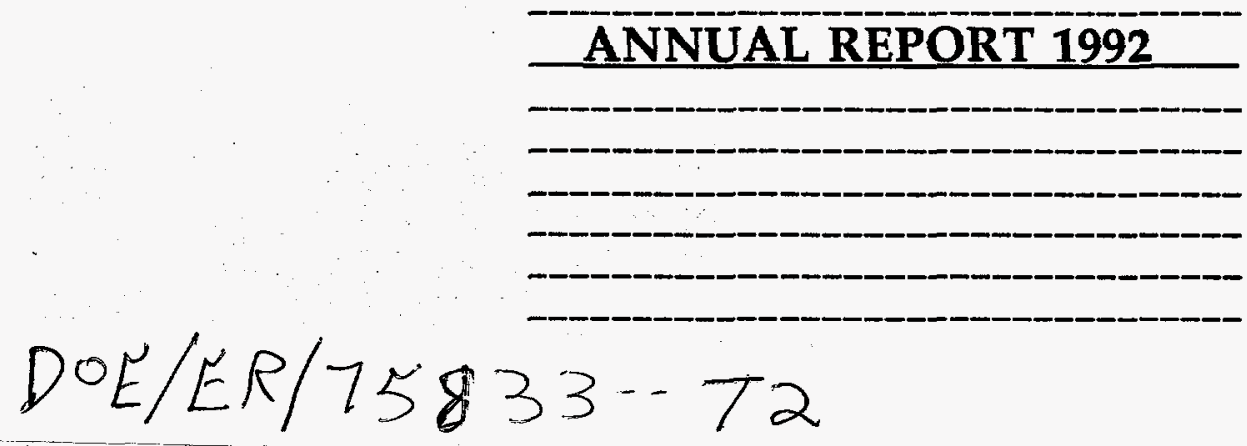

Science and Engineering Alliance, Inc.

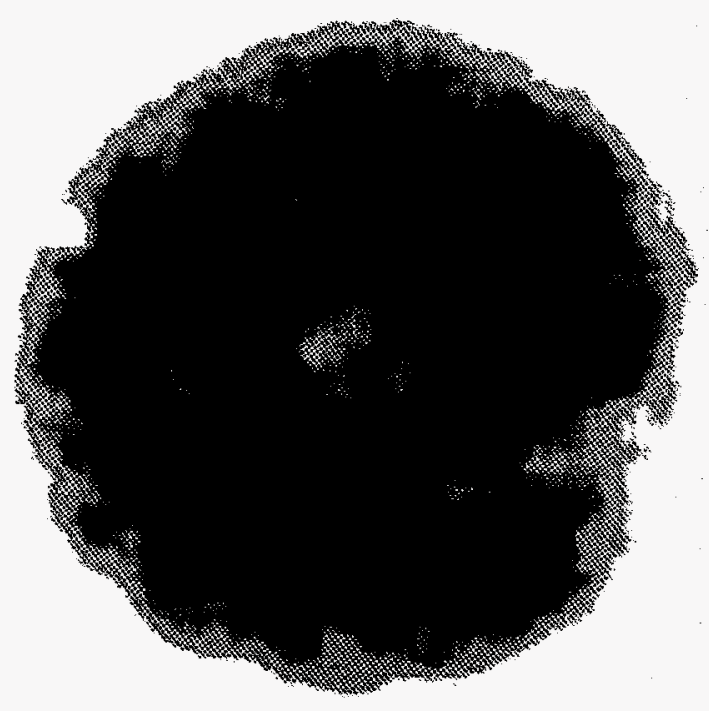

AAMUOJSUOPVAMUOSUBR ${ }^{\circ} L L N L$ JSUOPVAMUOSUBR ${ }^{\circ}{ }^{\circ} L{ }^{\circ}{ }^{\circ} A A M U$ PVAMUOSUBR'LLNLOAAMUOJSU SUBR ${ }^{\circ} L L N L{ }^{\circ} A A M U^{\circ} J S U O P V A M U$ LLNLOAAMUOJSUOPVAMUOSUBR AAMUOJSUOPVAMUOSUBR ${ }^{\circ} L L N L$ JSUOPVAMUOSUBR ${ }^{\circ}$ LLNL $^{\circ} A A M U$ PVAMUOSUBR ${ }^{\circ} L L N L{ }^{\circ} A A M U O J S U$ SUBR ${ }^{\circ} L L N L{ }^{\circ} A A M U O J S O Q P V A M U$ LLNL $^{\circ}$ AAMUOJSUO P AMUIOSU B̂R AAMUOJSUOPVAMU'OS $6 \mathrm{R}^{\circ} \mathrm{ZLNL}$ JSUOPVAMYrest BR ${ }^{\circ} L L N L A A A M U$ PVAMUOSER ON $N^{\circ} A$ AMUOJSU SUBROLLAY OA AMOJSUOPVAMU LLNI AAMUESUOPVAMUOSUBR AAMU OISUOPV SMUOSUBROLLNL JSLOP $A M$ OSUBR $^{\circ}{ }^{\circ}$ LNL $^{\circ}$ AAMU PXAYUOSUBOLLNLOAAMUOJSU SUBRELE L ${ }^{\circ}$ AAMUOJSUOPVAMU LLNLOAAMUOJSUOPVAMUOSUBR AAMUOJSUOPVAMU'SUBR ${ }^{\circ} L L N L$ JSUOPVAMUOSUBR ${ }^{\circ}{ }^{\circ} L N L{ }^{\circ} A A M U$ PVAMUOSUBR ${ }^{\circ}{ }^{\circ L N L}{ }^{\circ}$ AAMUOJSU SUBR ${ }^{\circ} L L N L{ }^{\circ} A A M U{ }^{\circ} J S{ }^{\circ}$ PVAMU LLNL' ${ }^{\circ} A A M U^{\circ} J S U^{O} P V A M U{ }^{\circ} S U B R$ AAMUOJSUOPVAMU'SUBR ${ }^{\circ} L L N L$ JSUOPVAMUOSUBR ${ }^{\circ}{ }^{\circ} L N L{ }^{\circ} A A M U$ 


\title{
DISCLAIMER
}

\begin{abstract}
This report was prepared as an account of work sponsored by an agency of the United States Government. Neither the United States Government nor any agency thereof, nor any of their bility for the accuracy warranty, express or implied, or assumes any legal liability or responsibility for the accuracy, completeness, or usefulness of any information, apparatus, product, or process disclosed, or represents that its use would not infringe privately owned rights. Refermanufactures trade name, trademark, manufacturer, or otherwise does not necessarily constitute or imply its endorsement, recommendation, or favoring by the United States Government or any agency thereof. The views and opinions of authors expressed herein do not necessarily state or reflect those of the United States Government or any agency thereof.
\end{abstract}

\section{COVER CAPTION}

On the cover is one of the first $x$-ray images ever produced by diffraction with an opaque sphere. Science and Engineering Alliance (SEA) students, working last summer at Lawrence Livermore National Laboratory (LLNL), were instrumental in making this and other similar recordings with $68 \AA \mathrm{x}$-rays. The recording is a densitometer scan of the shadow of a $625 \mu \mathrm{m}$ diameter sphere. The image of the source is the weakly illuminated region in the center of the shadow. It is called the spot of Arago. It took over 120 hours of exposure to make the image. This technique for making high resolution soft $x$-ray images may be very useful in both lithography and microscopy. 


\section{DISCLAIMER}

Portions of this document may be illegible electronic image products. Images are produced from the best available original document. 
Science and Engineering Alliance, Inc.

AAMUOJSUOPVAMUOSUBR'LLNL JSUOPVAMU ${ }^{\circ} S{ }^{\circ} \mathrm{PR}^{\circ}{ }^{\circ} \mathrm{LLNL}^{\circ} \mathrm{AAMU}$ PVAMU'SUBR ${ }^{\circ} L L N L{ }^{\circ} A A M U U^{\circ} J S U$ SUBR ${ }^{\circ} L L N L{ }^{\circ} A A M U O J S U O P V A M U$ LLNL ${ }^{\circ} A A M U U^{\circ}{ }^{\circ} U^{\circ} P V A M U{ }^{\circ} S U B R$ AAMUOJSUOPVAMUOSUBR'LLNL JSUOPVAMU'OSUBR ${ }^{\circ}$ LLNL $^{\circ} A A M U$ PVAMU'OSUBR ${ }^{\circ}{ }^{\circ L N L}{ }^{\circ}$ AAMU'JSU SUBR $^{\circ}$ LLNL $^{\circ}$ AAMUOJSUOPVAMU LLNL ${ }^{\circ} A A M U O J S U O P V A M U{ }^{\circ} S U B R$ AAMUOJSUOPVAMU'OSUBR ${ }^{\circ} L L N L$ JSUOPVAMUOSUBR ${ }^{\circ} L L N L{ }^{\circ} A A M U$ PVAMUOSUBR ${ }^{\circ} L L N{ }^{\circ}$ AAMUOJSU SUBR ${ }^{\circ} L L N L{ }^{\circ} A A M U^{\circ} J S U^{\circ} P V A M U$ LLNL ${ }^{\circ} A A M U^{\circ} J S U^{\circ} P V A M U{ }^{\circ} S U B R$ AAMUOJSUOPVAMUOSUBR ${ }^{\circ} L L N L$ JSUOPVAMU'OSUBR ${ }^{\circ}{ }^{\circ} L{ }^{\circ}{ }^{\circ} A A M U$ PVAMU'OSUBR ${ }^{\circ}{ }^{\circ}$ LNL $^{\circ} A A M U^{\circ} J S U$ SUBROLLNLOAAMUOJSUOPVAMU LLNL ${ }^{\circ} A A M U^{\circ} J_{S U}{ }^{\circ} P V A M U^{\circ} S U B R$ AAMUOJSUOPVAMU'OSUBR ${ }^{\circ} L L N L$ JSUOPVAMUOSUBR ${ }^{\circ} L L N L O A A M U$ PVAMU'OSUBR ${ }^{\circ} L L$ SL $^{\circ}$ AAMU'JSU SUBR ${ }^{\circ} L L N L{ }^{\circ}$ AAMUOJSUOPVAMU LLNL ${ }^{\circ} A A M U O J S U O P V A M U{ }^{O} S U B R$ AAMUOJSUOPVAMU ${ }^{\circ}$ SUBR $^{\circ} L L N L$ JSUOPVAMU'OSUBR ${ }^{\circ}{ }^{\circ}{ }^{\circ}{ }^{\circ}{ }^{\circ} A A M U$ 


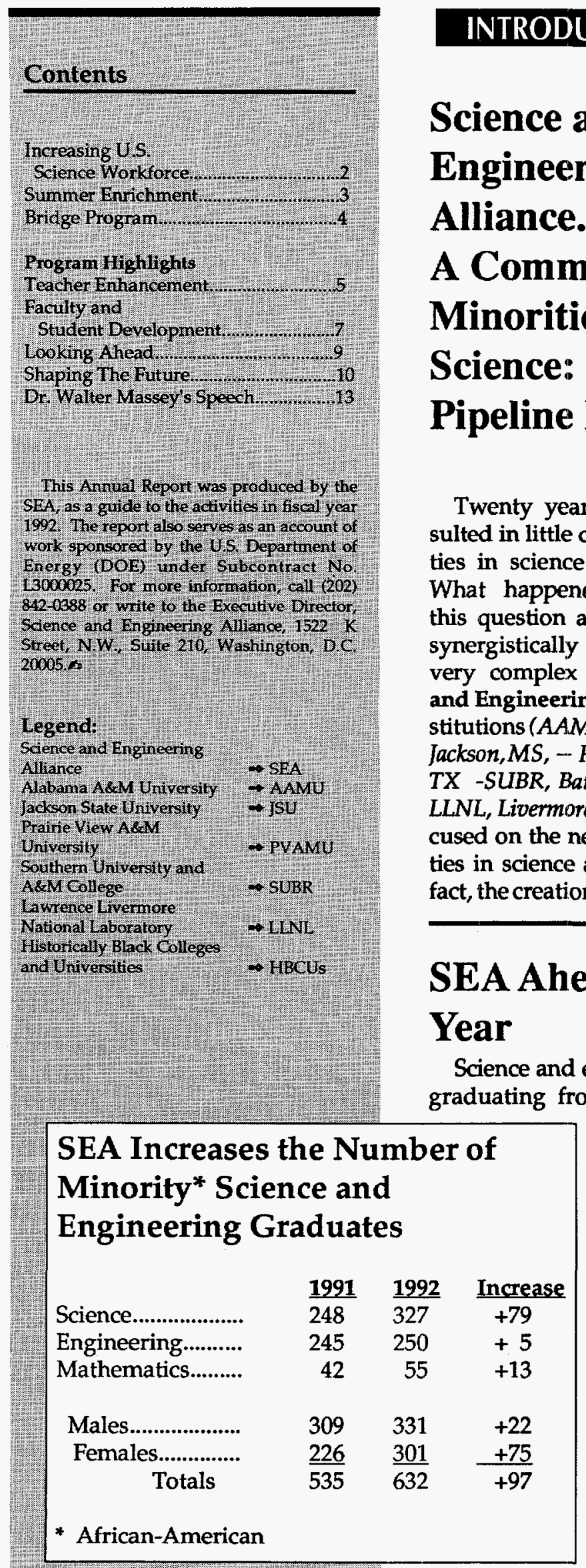

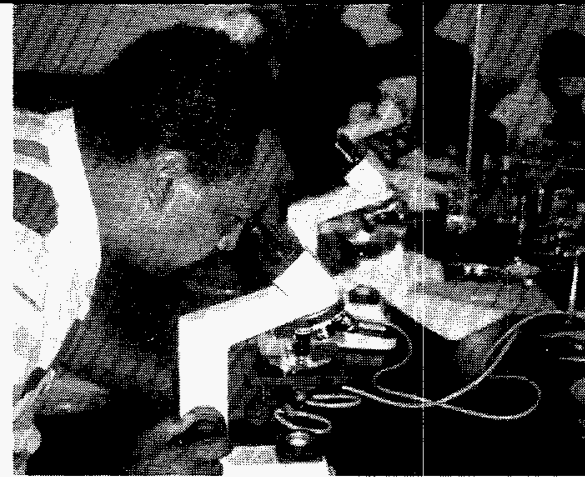

stration of how the member institutions continue exploring new and innovative ways of addressing the pipeline problem. Combining their resources and appointing a fulltime director to oversee this longterm effort shows commitment.

This Annual Report reviews SEA activities that occurred in 1992 to address the minorities in science problem. The commitment to this challenging problem is evident in the many programs and creative efforts described in this report. Because SEA believes commitment begins with accountability, this report contains FACTS and FIGURES that demonstrates actual accomplishments by SEA during fiscal year 1992 (the year ending September 30, 1992). Where warranted, the report highlights events from the last quarter of the calendar year.ts

majors are declared through graduation. The programs are working. For example, the SEA accounts for approximately $11 \%$ of the 1992 African-American engineeringgraduates ( 250 out of a total of 2,374 ).

Since its formation in late 1990 , SEA focuses on achieving steady increases in the graduation rate of its students by building on the legacy and success of existing programs. Special emphasis is placed on enhancing programs that direct more African-American males toward science, engineering, and mathematics. The number of minority students graduating in technical fields from SEA institutions is significant since many of the students must work jobs off campus to help finance their education.tes 


\section{Increasing the U.S. Science and Technology Workforce}

The SEA plan for Increasing the U.S. Science and Technology Workforce is an effort to address the shortage problem of human resources for science and technology needs in the future. The SEA strategy focuses on increasing the number of minority scientists and engineers in the education pipeline from pre-college through undergraduate and graduate school by: (1) increasing the participation of minority faculty and students in high-quality scientific research activities; (2) expanding the number of summer internship and coop programs for students; (3) providing greater opportunities for minority faculty and students to participate in technical conferences, workshops and seminars; and (4) providing scholarship support for worthy students. An important aspect of SEA's effort is that it represents a shared commitment of four HBCUs spread over four states.

But the plan goes a step further by emphasizing the need for K-12 science and mathematics teachers to be better prepared to teach their subject matter more effectively. This issue is critically linked to the shortage problem. Having a greater understanding of the role they must play helps teachers in the "collective push" to ensure the pipeline problem is addressed at all levels. The plan calls for direct interaction between SEA faculty and staff, and teachers of science and mathematics in grades $\mathrm{K}-12$. The implementation consists of enhancement workshops for high school mathematics and science teachers on the campus of

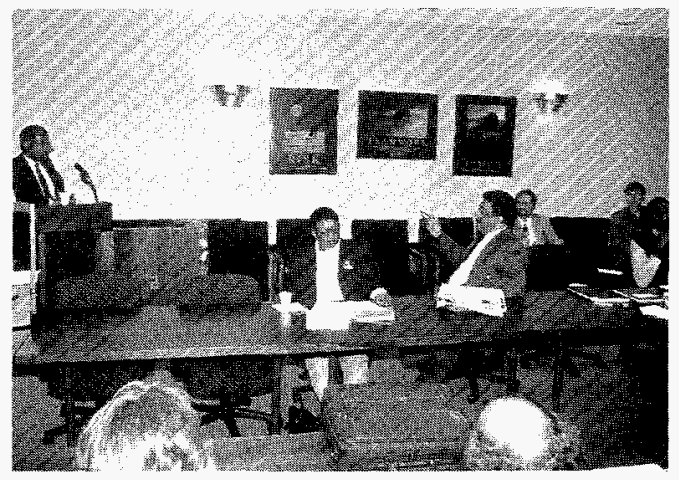

each SEA institution (see page 5). The evolving plan, which the Board of Directors approved in April 1992, is the central planning document for the implementation of SEA programs and support services. The plan provides the basis for focusing SEA's collective attention on the pipeline problem and the many available opportunities for SEA faculty and students. Additionally, the plan reflects realistic numerical goals based on past accomplishments.

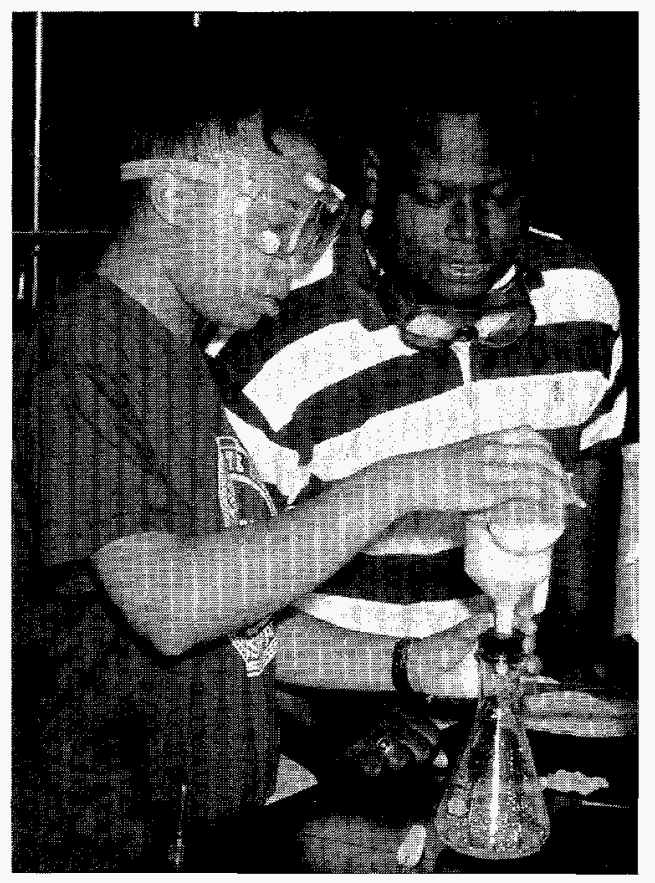

A Commitment to the Pipeline Problem

SBA Boarat of Directors:

Generall wink W. Becton, I. Chaiman

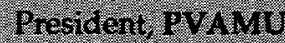

D. David B. LIenison

President, AATl

Drt lames, 2 , 1 , rons, 5 . President TSU

Dr. Marvin L, Yates Chancellor, SUBR

Dr. Whil E, Cogle, Ir: Assoclate Laboratory Director, LI.LU,

\section{SEA Steering} Committee:

\section{PVANIT}

Di. Willie E: Trolly.

Chairman

Dr. John Willams

it)

Dr. Jeanetre lones

Di. Aing Daniel

J5U

D. Bettre Wf Fleteher

Dr Ab.dal Mohamed

(8) $3 \mathrm{~B}_{\mathrm{B}}$

Dr. Whiarn E Moore

Dr. Nusrat Nagyi

IITIS.

N1t James Evans:

Execulnve Director Di. Robert L, Shepara 


\section{FACTS and} FIGURES

\section{SEA Summer Programs}

\section{LLNL -12 slots}

Techuical Areas:

Chemistry

Computing

Environmental Science

High Performance

Material Science

Optics

Physies

\section{Corps of Engineers - 4 slots}

Technical Areas:

Chemistry

Chemical Engineering

\section{Enrichment}

\section{Through Summer \\ Programs}

SEA faculty and students continue to benefit from participation in summer research activities. These summer programs provide valuable experiences and open opportunities for exploring new ideas. The training gained by working in a real-world environment allowsstudents to shape career objectives and build technical networks for the future. These experiences help faculty tailor educational programs to produce graduates that are ready to step into responsible technical positions in industry,government, and academia.

The summer program at LLNL is a good example of how one program is investing in the future production of minority scientists and engineers (see page 7).ts
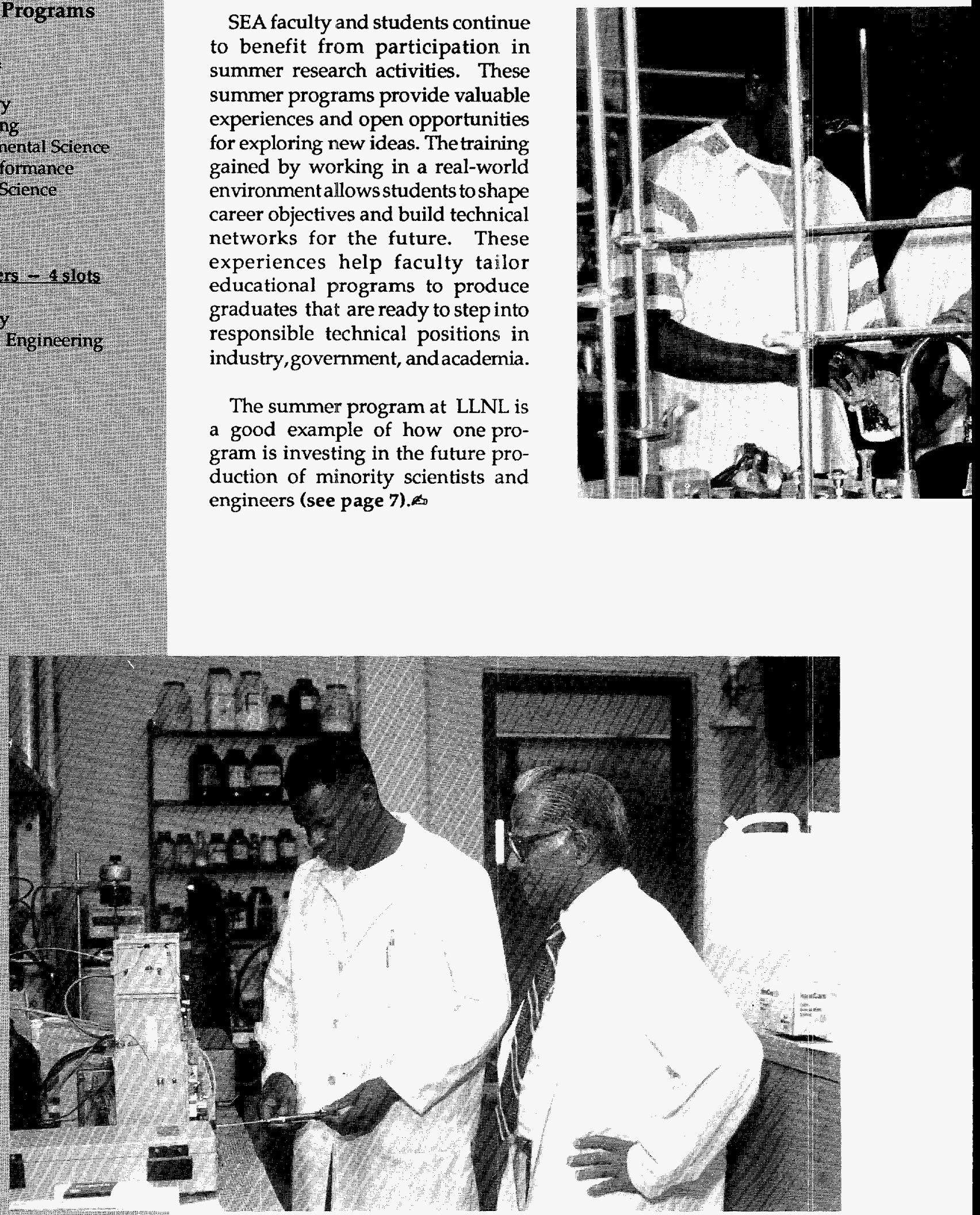


\section{Bridge Programs Make A Difference}
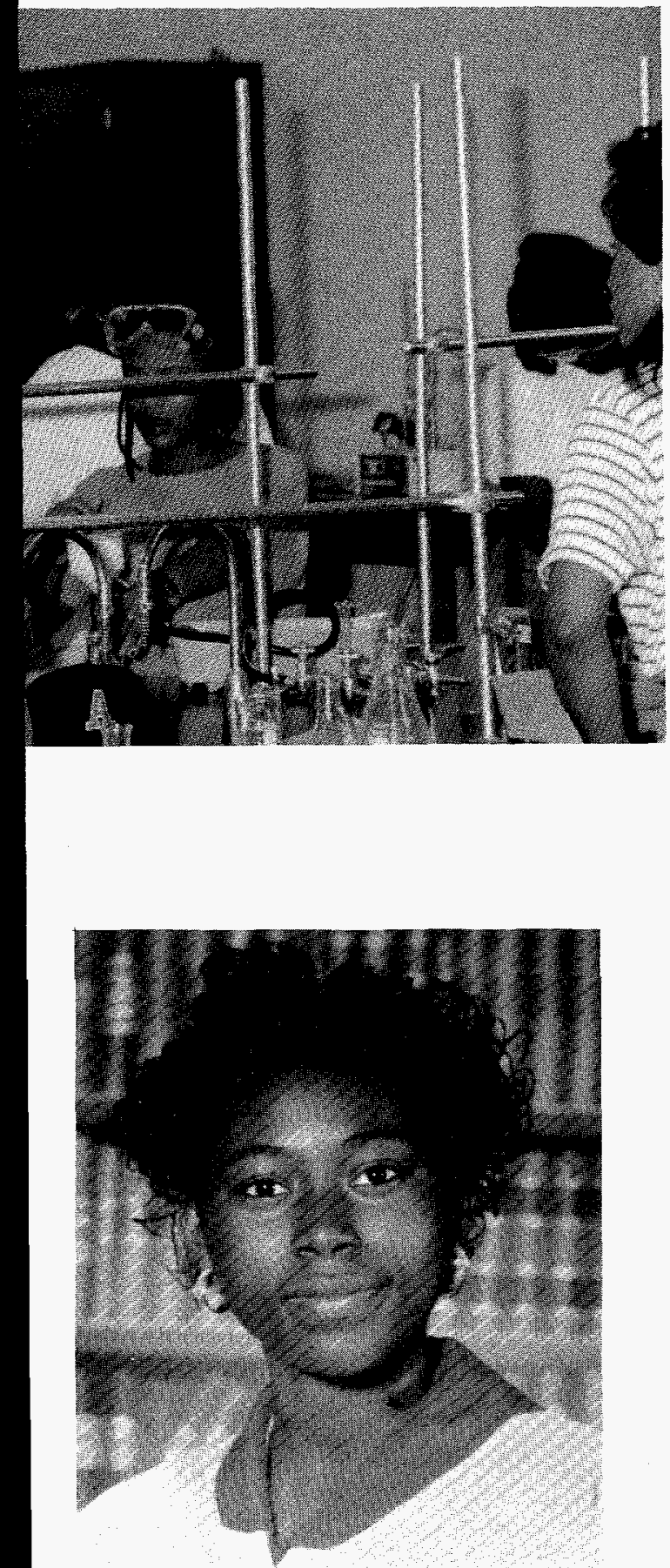

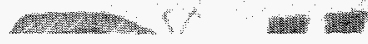

SEA continues to reap benefits from its wide-range of programs that are designed to help minority students make a smooth transition from high school work to college-level course work. These programs, commonly referred to as "Bridge Programs," take students that demonstrate high academic potential and immerse them into a variety of advanced college-level course work. The students are brought to campus during the summer following graduation from high school and placed in the program. The summer activity incorporates both classroom lectures and laboratory exercises. At times, recent high school graduates work with graduate and undergraduate students in an off-campus research experience. Such an activity can be extremely rewarding in motivating students to continue to excel.

An example of a SEA Bridge Program success is reflected in Ms. Ranti Bushura. Just last year, Ranti was a graduating senior from Cardoza Senior High School in Washington, D.C. Because of her outstanding high school performance in science, SEA honored Ranti by making her an Incentive Award recipient. The award is given annually by SEA to high school students with a demonstrated interest and involvement in science and mathematics. Following graduation, Ranti was awarded a full academic scholarship to study chemistry at JSU. During the first semester at JSU, Ranti pulled a 4.0 grade point average. Ranti says "the Bridge Program helped me get off to a good start with college work. "Æ
FACTS and

TIGUNES

SEA member institutions host more than 30 swmer emrehment programs for minonity youth in grades 6, 12. The programs indide:

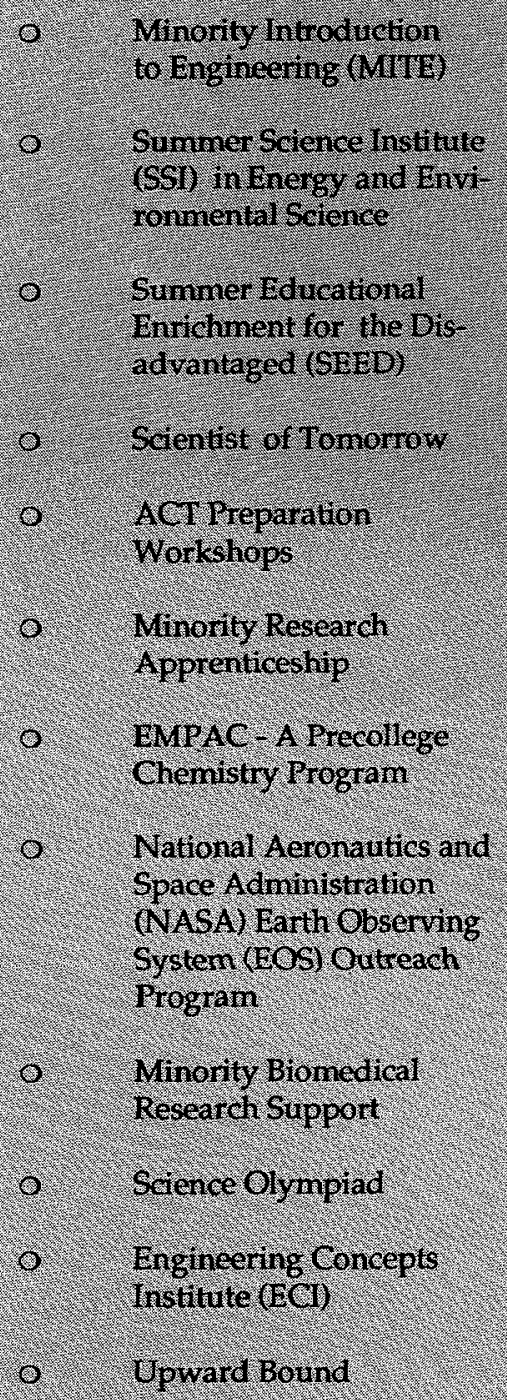

For more information on SEA enrichment programs, call $(202) 842-0389$ or wite to the Exeeritve Director, Science and Engineering Alliance, $1522 \mathrm{~K}$ Street, N.W. Suite 210 , Washington, DC. 20005.6 
FACTS and FIGURES

\section{SEA Teacher \\ Enhancement}

1992 Workshops:

June 1-19, 1992

0 AAMU,

o JSU

o. SUBR

June $15-J u l y ~ 3,1992$

O. PVAMU

\section{Areas Covered:}

O Biology

o. Chemistry

0. Earth Science

o Environmental

Science

0 Physics

Schedule:

30 hours per week

( 6 hours/day $\times 5$ days)

Number of Participants:

85. Teachers

(8 lead teachers)

Evaluation:

$88 \%-100 \%$ of participants rated workshops as highly

beneficial.

Distribution of Results:

Over 600 copies of a work-

shop module entitled,

"Teacher Learning Strategies

That Enhance Knowledge: The

Concept of Cognitioe Conden-

sation," were distributed to

teachers in Louisiana.

Supported by:

0. Funds for Improvement of Postsecondary Education (IIIPSE)

$0 \quad$ U.S. Department of Energy (DOE) ts

\section{PROGRAM HIGHLIGHTS}

PRE-COLLEGE

\section{Enhancing the \\ Teacher \\ Workforce}

During the summer of 1992, SEA held a series of teacher enhancement workshops for high school science and mathematics teachers. The workshops were the first of a series to be held over the next three years. The contents of the workshops consist of the basic principles of several science subject areas, and were conducted by SEA faculty members with expertise in the various fields. The SEA professors were assisted by two (2) lead teachers at each workshop site.

Workshop class activities include lectures, hands-on laboratory exercises, demonstrations, and tours. It is too early to report concrete results; however, the participants re sponded enthusiastically to the firstyear's effort. Upon completion of the workshops, LLNL sponsored a visit to its Science Education Resource Center for the eight lead teachers who had key roles in the workshops. The teachers were exposed to a variety of enrichment activities that they would share with fellow teachers and students in the Fall. Further steps toward institutionalizing the SEA teacher enhancement workshops and disseminating the results to regions external to the SEA will be introduced in 1993.

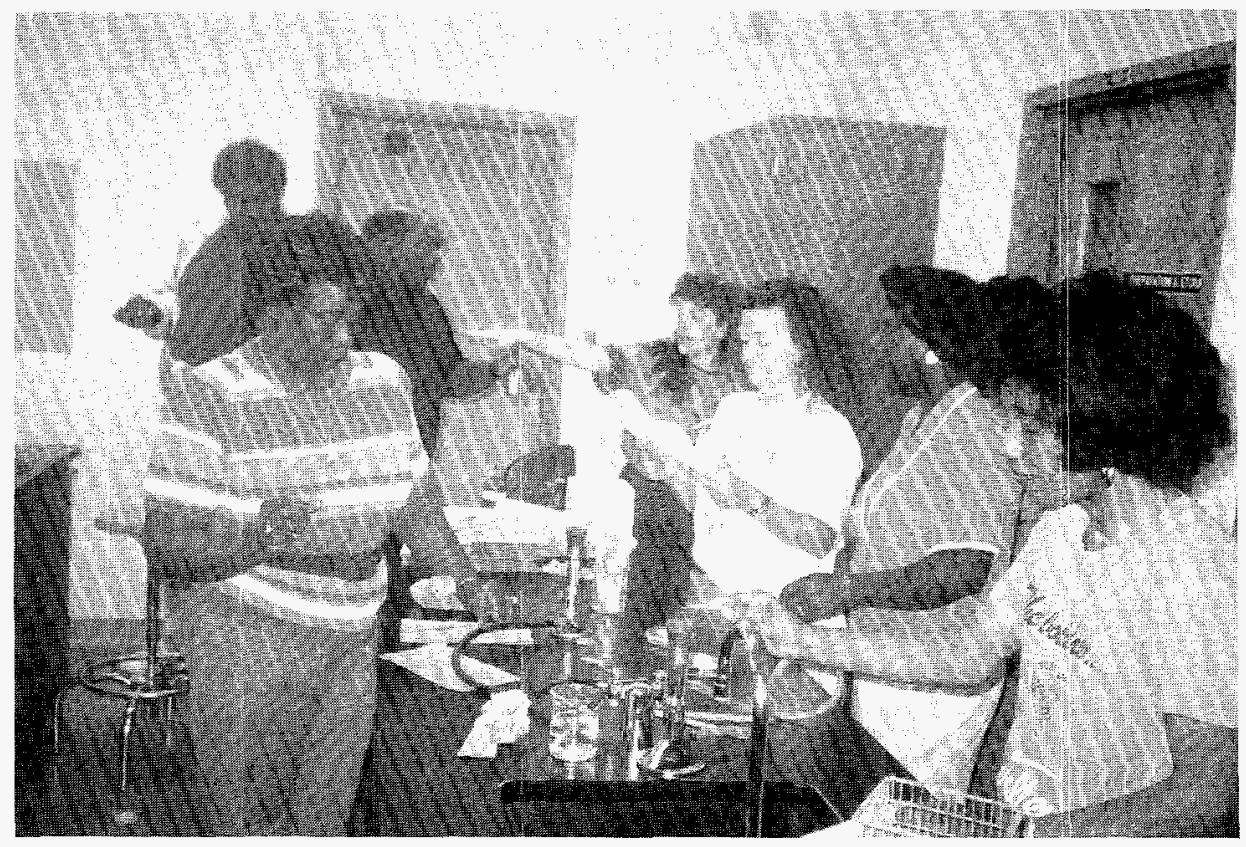




\section{SEA Faculty Host SuperComputer Workshop For Science and Mathematics Teachers}

Each year, LLNL hosts a summer SuperComputer workshop. Thegoal of the workshop, sponsored by the National Energy Research SuperComputer Center (NERSC), is to train individuals to access the SuperComputer for use in their local region. During the summer of 1992, SEA faculty from JSU and PVAMU took part in the training program.

Projects presented during training included a ray training project and a climate modeling project. The ray training project allows students to interactively construct threedimensional worlds using standard geometric shapes. Students use this advanced computer graphics technique to produce high-quality animations. The climate modeling project allows students to simulate global climate change by altering parameters such as ozone levels, carbon dioxide concentration, surface type, ocean temperatures, and cloud cover.

Upon returning to his campus, $\mathrm{Mr}$. J. D. Oliver, hosted a workshop at PVAMU to train local area science and mathematics teachers on how to access and utilize the National Education SuperComputer (NES). Access to the SuperComputer resource provides teachers with a tool for simulating classroom activities using the ray training and climate change projects, as well as some others. \&

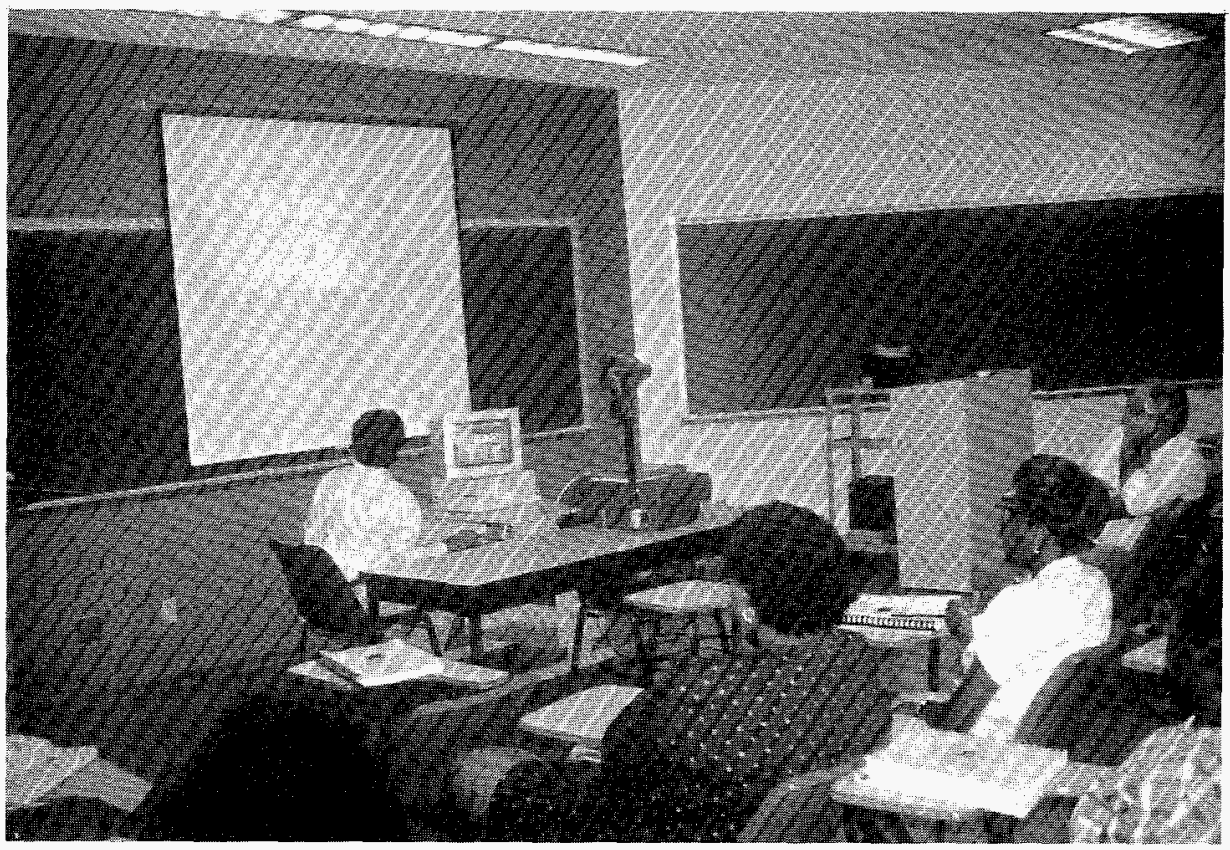

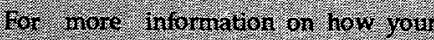
saleol distitet can nake ise of the

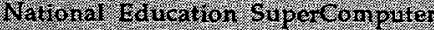

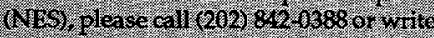

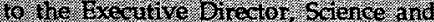

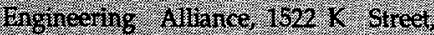
N.V. Sure 210 , Wasting bon, DC 20105.5 


\section{FACTS and FIGURES}

\section{Program Results:}

$0 . \quad$ Supment of electron field emission equipment from LENL to ISU for continuation and expansion of the research activity.

0 JSU student, Kevin Wansley. recelved a Research Careers for Minority Scholars (RCYS) scholarship for the 1992-1993 acadenic year

\section{Publications in Progress:}

0. Mensurement of Electron Field Emission Using Energy Dis. persive Particle Counting Temigues, T. James, $\mathrm{T}$. Terry, K. Wansley, P. Ebert.

0 iDifraction of Ligh by An Opaque Sphere Imaging soft X-ray, "R. Posey, D. Brown, T. Swint, K. Broad water, I. Valentine, $\mathrm{P}$ Ebert $\mathrm{C}$.
FACULTY and

STUDENT DEVELOPMENT

\section{Lawrence}

Livermore

National

Laboratory

and SEA Benefit

from Summer

Program

The LLNL summer program is designed to foster and encourage collaborative research among faculty and students of SEA and personnel of LLNL. The program serves as the primary vehicle for the exchange of students, faculty, and staff members between SEA and LLNL. The goals of the program are to: (1) coordinate the scientific, technical, and creative resources and talents of the SEA member institutions; (2) advance the knowledge in the fields of physical sciences and engineering; and (3) enhance the research infrastructure at the SEA member institutions.

During the summer of 1992, JSU

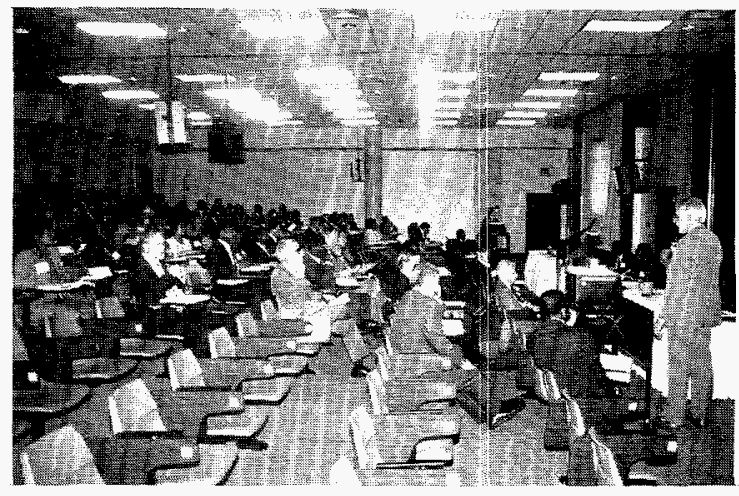

professor of physics, Floyd James and two of his students made excellent progress on a research project entitled "Measurement of electron field emission using energy dispersive particle counting techniques."

Their experiment confirmed some earlier LLNL measurement results. Obtained with entirely different apparatus and experimental conditions, including a significantly broader range of accelerating voltage, Professor James and his group's results suggest that several electrons are emitted simultaneously in a single field emission event. This result, if confirmed, could lead to a number of very attractive technological applications.tos

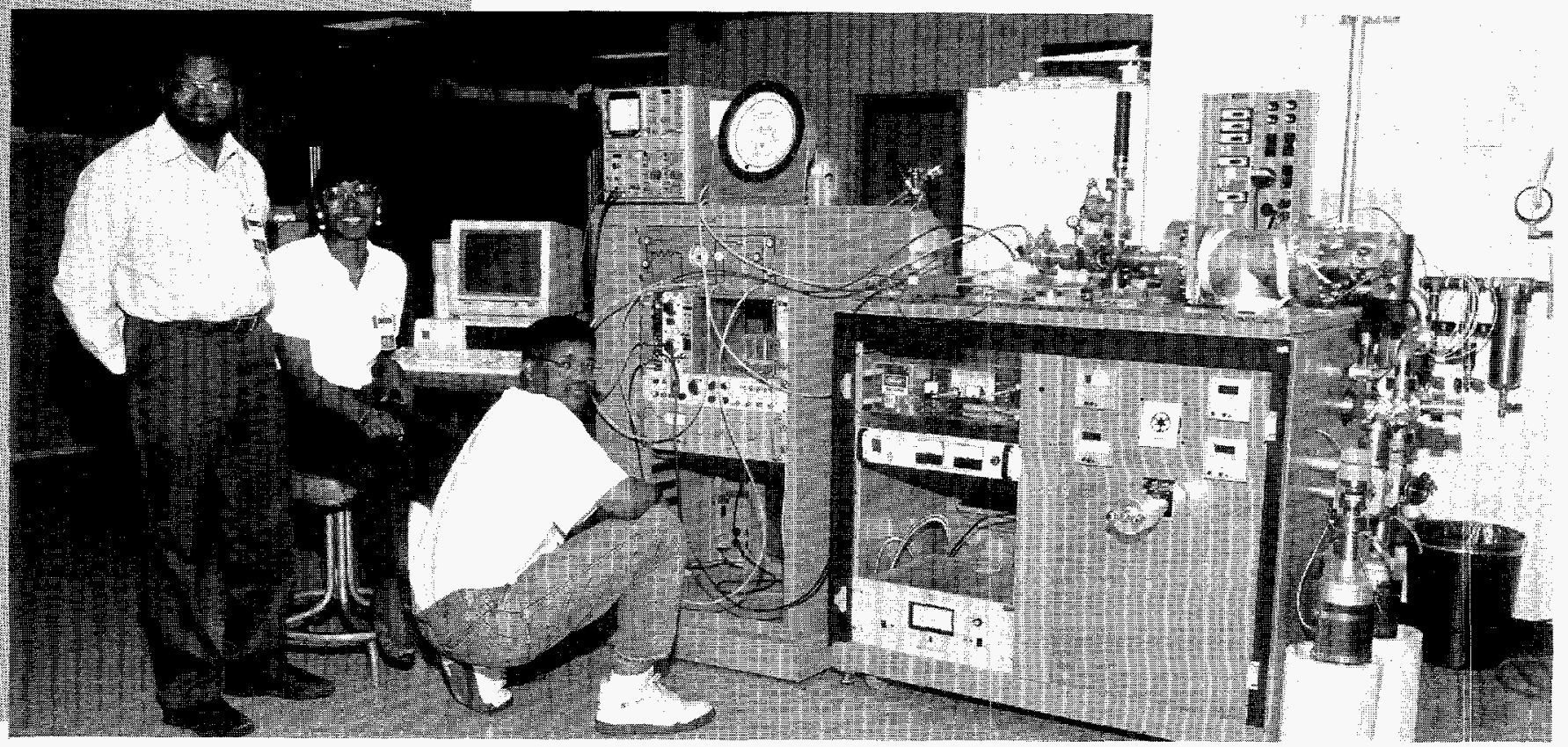




\section{SEA Students Present Findings in Puerto Rico}

SEA students continue to benefit and gain experience from participating in technical conferences and seminars like the Waste Management Conference '92 that was sponsored by the U.S. Department of Energy (DOE). Students are encouraged to search the literature, and develop skills in relating published results to their own work. SEA provided travel support for five students to participate in technical exchange at the DOE conference that was held in Puerto Rico. Identifying opportunities for SEA students to expand and grow is an important part of SEA's commitment of sharing in the development of a well-qualified and diverse technical talent pool.ts

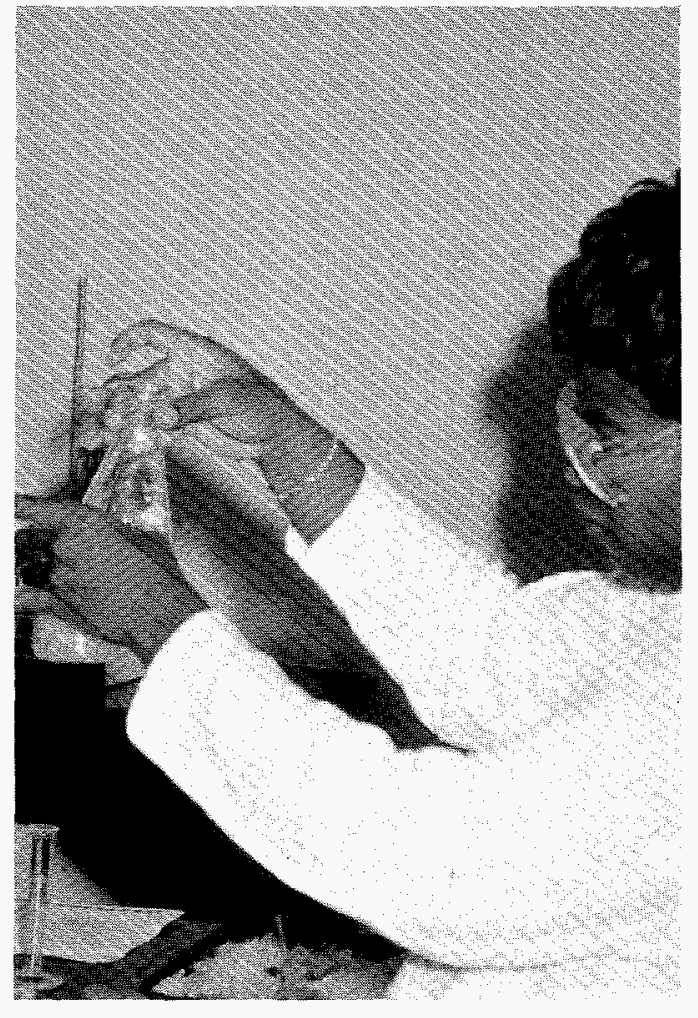

\section{FIGURES}

\section{Student Abstracts:}

0. "A Comparisor of the Ceriodaphnia dubia and Bacilus licheniformis Acute Toxicity Tests Utilizing Enwronmental Semples,

K. Haslett, A AMU

o : - Fabrication of Carbon Win dows for the Environmental Cell of the Transmission Electron Microscope,"

S. Wells, ISU

0. Imaging Surfaces with the Scanning Tumeling Micro: scope, :

M. Girfin, ISU

0. $\quad$ Patterns in Resoloing Systems. Discrimination Between Bru cine Salts of Allhydrogen Phthalates and Ephedrine Salls of Halomandelates,

S. Varma, JSU

"Disposal of Medical WastesTwo Options:

N.Savage, PVAMU

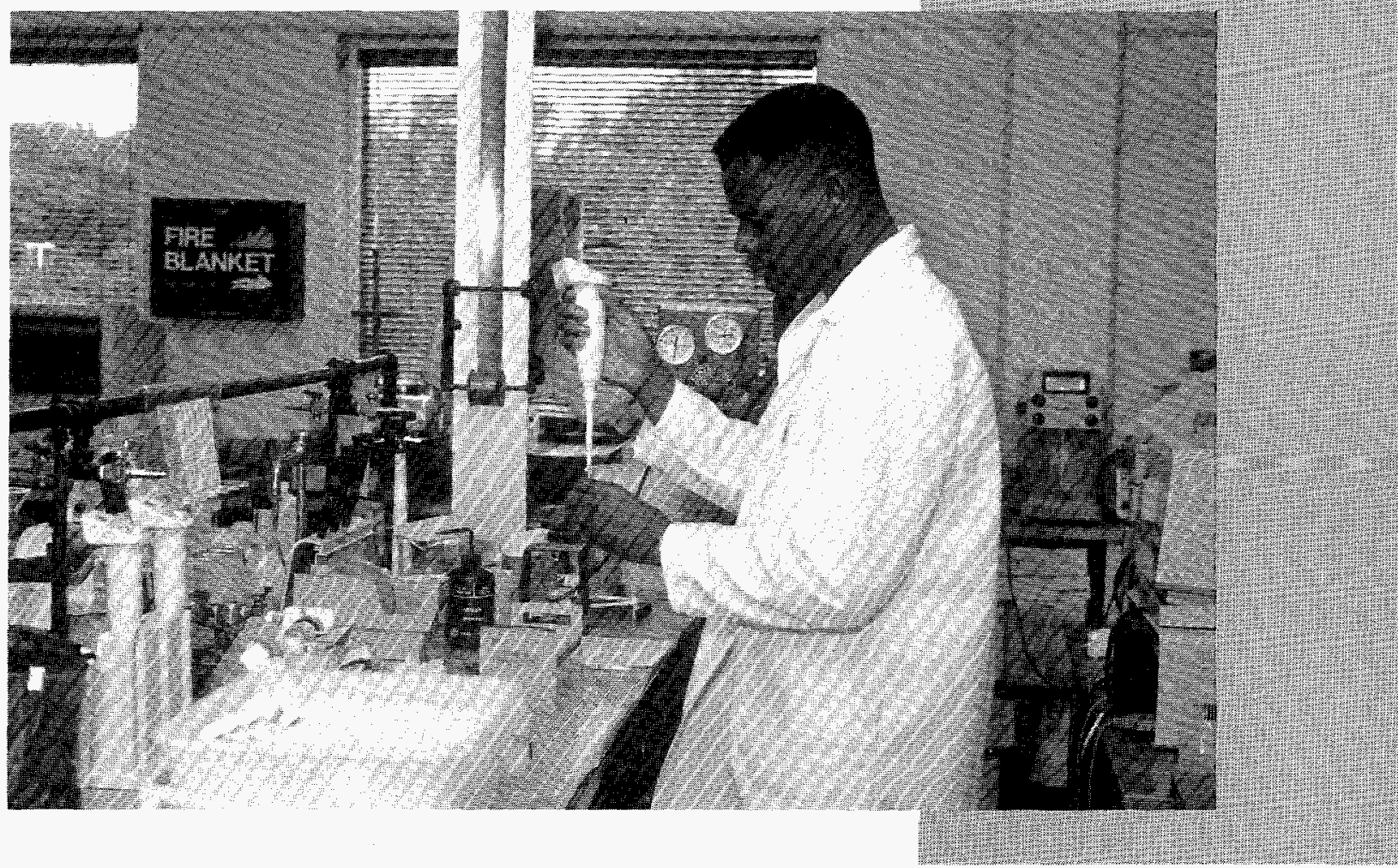




\section{FACTS and \\ EIGURES}

\section{SEA DESIGN TEAMS:}

Technical personnel working together to define a research agenda for SEA.

\section{DESIGN TEANA:}

Synchrotron Beamline (SEA sym):

0. Installation of a Broadband (UV to Hard X-ray) Radia tion Beamilne at CAMD for SEA Users.

\section{DESICNTIEAM B;}

The Mississippi River Project

0. Water Qualty Relationship to. Economic Impacts Along The Mississippi River:

0. Applications of Modeling of Miorobial System to Bioremediate Roint and Non-Point Sources.

0. Development of Rsk Sensitivity A naly sis to Critical R/A Parameters and Development of Means to Measure Uncertainty Associated with those Parameters:

0 Assessment of Sources of Pollution Along the Misst ssippi River.

\section{DESTCHTEAME:}

Wigh Performance Computinet Clobal Ehange itoject
0. Blotechnology and
Biomedical Studies.
0. Data Acquisition, Storage: Trocessing and Integration.
6. Irgh Performance
Computing: Issues in Materials Science and Muid Flow ts

\section{RESEARCH}

\section{Looking Ahead}

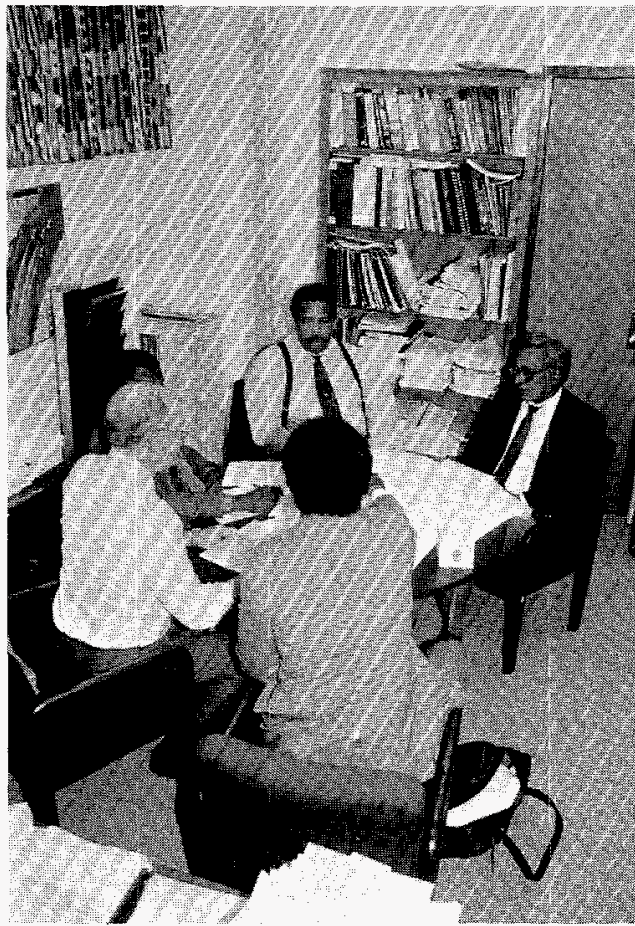

In 1992, the Steering Committee took steps to define a research focus for SEA. Using the "Design Team" concept, SEA research faculty and LLNL technical personnel were brought together to develop comprehensive research proposals. During 1992, Design Tearns began developing concept papers for research in high performance computing, global climate change, and environmental restoration. These discussions led to the development of several proposals in 1992. Additional discussions were initiated in 1992 between SEA and Louisiana State University's (LSU) Center for Advanced Micro-Structures and Devices (CAMD) concerning the installation of a synchrotron beamline facility for SEA faculty and student researchers.tes

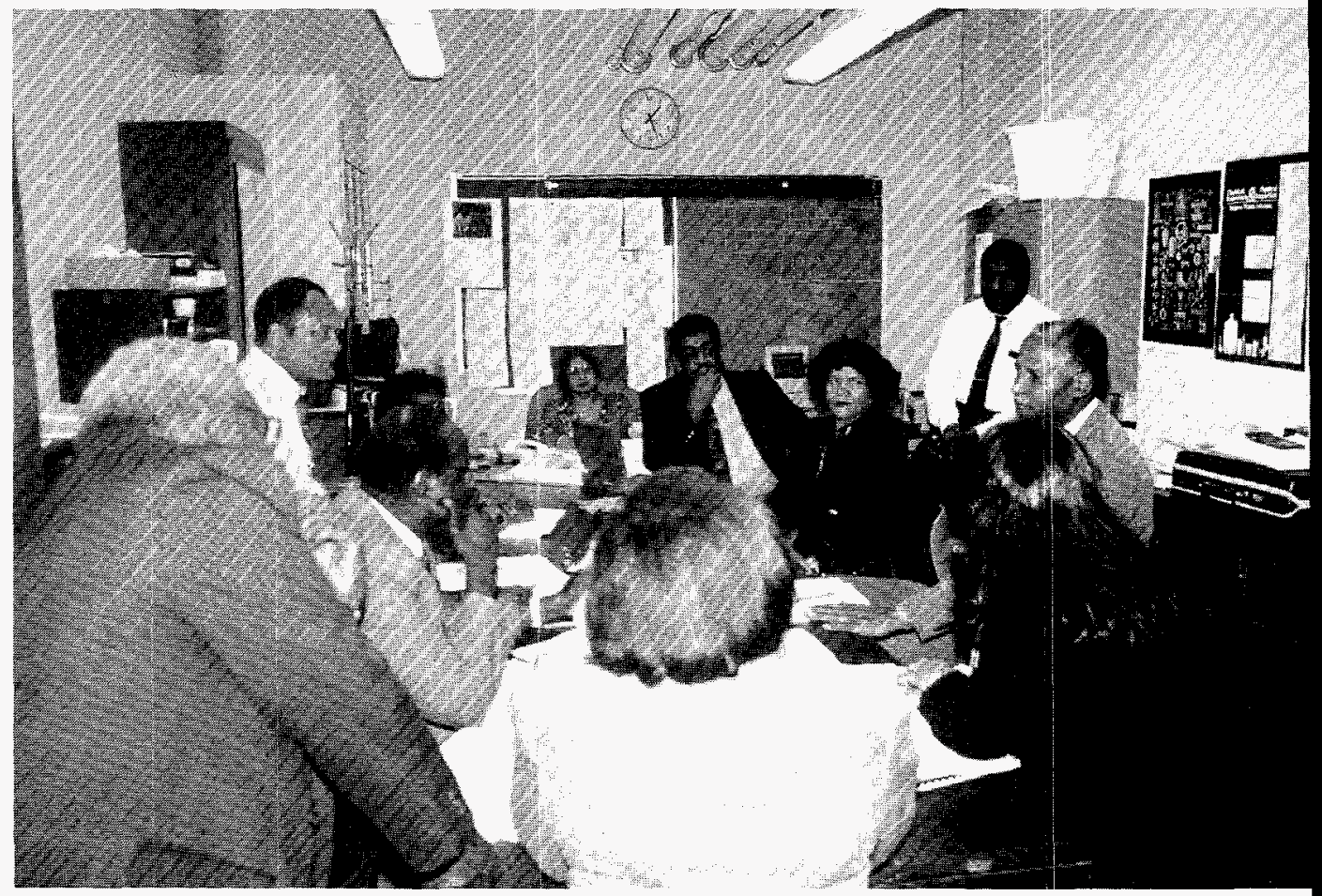




\section{Shaping the Future}

We indicated at the First Annual SEA Scholarship and Incentive Awards Banquet that special emphasis is placed on increasing African-American male participation in science and engineering programs. Unlike 1991, when only one of the ten students honored was an AfricanAmerican male, of the twenty (20) students that received SEA scholarship and incentive awards for 1992, seven $(7)$ were males.

Here is what one of the 1992 high school recipients had to say about SEA's scholarship program:

"My experience with the SEA was very beneficial and enlightening. Acknowledgment by the SEA brought to my attention that there are people who care about the future. If feel the SEA is working for a better tomorrow. Meeting the influential, prestigious AfricanAmericans, was a heart-warming experience. It confirmed within me that there are some people of my ethnic background that are striving despite the odds.

The SEA gave me an opportunity to meet and exchange ideas with other young, goal-seeking AfricanAmerican youth. Such an experience has given me the inspiration to continue to aim high because I am not alone in the struggle to succeed. Never in my life has receiving an academic award felt so complete. Receiving the SEA Incentive Award has given me a sense of accomplishment. It makes me feel proud and distinguished. The SEA award expresses to me that my hard work has not gone unrecognized.

When I am occasionally rewarded for my accomplishments, it lets me

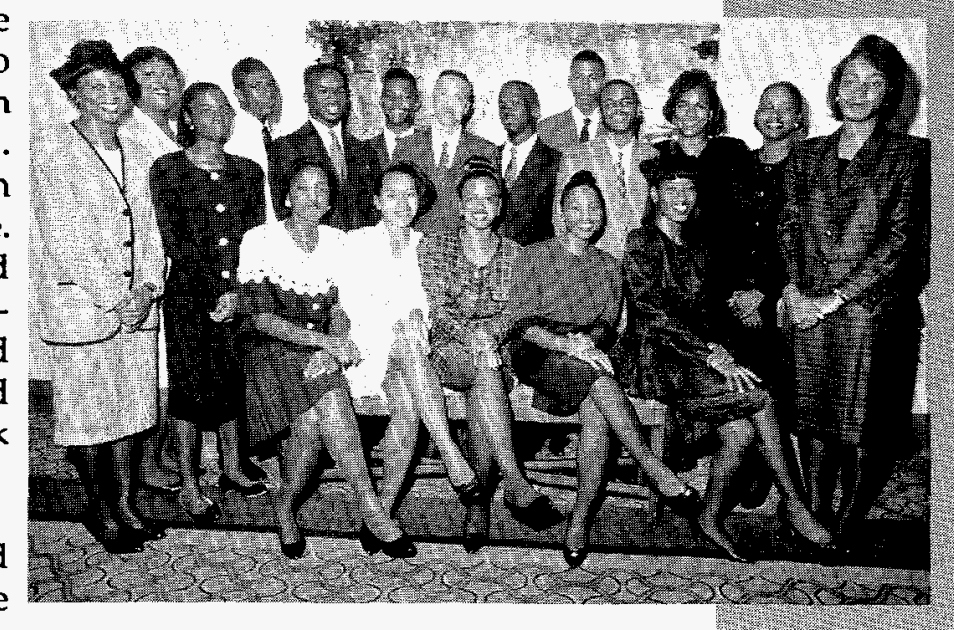

2nd Annual Scholarship \& Incentive $A$ ward: Barguet.

Where

Ramada Techworia Ballroom in Washington, DC

Whint Gerober9.1992.

Mrster of 2 General Julius

Cerenioniest. Becton, If. President, PVAMH thing. This experience influences me to keep striving, especially the speech given by Dr. Walter Massey. I realize now that most of my life is spent preparing for the future, but the rewards will be well-worth the time spent achieving them. To sum up my SEA experience, I would use three words: beneficial, motivational, and learning. The Science and Engineering Alliance has touched my life in a major way."

Vanessa Marie Turner Alabama

Dr. Walter Massey, Director of the National Science Foundation (NSF), gave an inspirational address to the students. His complete speech begins on page 13 of this report.

\begin{tabular}{|c|c|}
\hline Keyot & Dr Waller E. \\
\hline Sperien & Wassey \\
\hline & Director \\
\hline & Foundation. \\
\hline Wh Altentance. & 200 guests \\
\hline & Indualing Wgerian \\
\hline & Excellency \\
\hline & Nalam Zubair \\
\hline & Lazaure \\
\hline
\end{tabular}

1992 Howreres: Ayesha Muhammad Konishaw, Darlene Davis, Tanya Harris, Niambi White, Theodore Lyons!I, Richard Crews: Angelica Duntap. Lajuan lones, Benny. Cox. 11 Bennyter Bridgewater, Vanessa. Timer Vastika Fomester, Aisita Swinton, Willan Dur. Caliph Ionison, I. Crats Pince, Renjatta Momison, and Rissel cavilfeld.

Awards to Each: Framed centhicate and 51,500 to each college student and $\$ 100$ to each high school student $s$ 
HBCUs. Alabama A\&M University and Prairie View A\&M University, also, are key members of Alliances in their regions. Currently, we are providing up to $\$ 1$ million annually to each of eleven alliances, matching the support each has raised from within their own communities; next year, we plan to solicit proposals for additional Alliances.

One key aspect of this program is that the participating institutions are accountable to meet numerical goals they have set. For example, the eleven existing Alliances currently graduate 8,000 minority students in science and engineering; together, they are committed to doubling that number in five years. Annual reviews will determine whether each Alliance is achieving its specific goal; continueNSF support depends upon their demonstrating significant and measurable progress.

Many of you here, tonight, are already involved in AMP and other NSF-supported activities designed to improve science and engineering education, to increase minority participation in these fields and, thereby, strengthen the U.S. research enterprise. I invite the rest of you to join us also.

The students we are recognizing tonight have demonstrated not only their interest, but also their ability to compete and contribute in science and engineering. They have taken the first steps towards challenging and rewarding careers in these fields. NSF is committed to assisting their progress toward that goal, and we welcome your involvement.

\section{Conclusion}

Almost fifty years ago, Vannevar Bush published Science - the Endless Frontier. In that document, he laid out a blueprint for Federal support of science and engineering research and education, a blueprint that would be the basis for the NSF charter. He talked about a plan for assuring scientific leadership and said:

"We think it is much the best plan ... that opportunity be help out to all kinds and conditions of men [and women] whereby they can better themselves. This is the American way; this is the way the United States has become what it is. We think it is very important that circumstances be such that there be no ceiling, other than ability itself, to intellectual ambition. We think it is very important that every boy and girl know that, if he [or she] shows that he [or she] has what it takes, the sky is the limit. Vannevar Bush had a vision of America's scientific and technical community. I invite you to join us in making that vision the reality.

Thank you for inviting me to be part of this important event.tes

\section{REFERENCES}

1. National Science Foundation. 1992. Blacks in Undergraduate Science and Engineering Education. p.62.

2. National Science Foundation. 1992. Selected Data on Science and Engineering Doctorate Awards: 1991. p.3.

3. National Science Foundation. 1992. Selected Data on Science and Engineering Doctorate Awards: 1991. p.20.

4. National Science Foundation. 1992. Blacks in Undergraduate Science and Engineering Educa tion. p.26.

5. National Science Foundation. 1992. Blacks in Undergraduate Science and Engineering Educa tion. p.9. 
SCIENCE AND ENGINEERING ALLIANCE, INC.

1522 K Street, N.W., Suite 210

Washington, D.C. 20005

(202) $842-0388$

FAX (202) 842-0403 